\title{
Osteopontin Promotes Invasion, Migration and Epithelial-Mesenchymal Transition of Human Endometrial Carcinoma Cell HEC-1A Through AKT and ERK1/2 Signaling
}

\author{
Yinghua Lia Yunpeng Xie ${ }^{a, c}$ Dan Cui ${ }^{a}$ Yanni Ma ${ }^{a}$ Linlin Sui Chenyang Zhu ${ }^{a}$ \\ Hui Kong ${ }^{\text {b }}$ Ying Konga \\ aDepartment of Biochemistry and Molecular Biology, Dalian Medical University, Dalian, bepartment \\ of Otorhinolaryngology of the Second Hospital, Dalian Medical University, Dalian, 'Department of \\ Cardiology, Institute of Cardiovascular Diseases, First Affiliated Hospital of Dalian Medical University, \\ Dalian, P. R. China
}

\section{Key Words}

Osteopontin • Endometrial cancer • Migration • Invasion • EMT

\begin{abstract}
Background/Aims: Osteopontin (OPN) is an Extracellular Matrix (ECM) molecule and is involved in many physiologic and pathologic processes, including cell adhesion, angiogenesis and tumor metastasis. OPN is a well-known multifunctional factor involved in various aspects of cancer progression, including endometrial cancer. In this study, we examined the significance of OPN in endometrial cancer. Methods: The proliferation, migration and invasion ability of HEC-1A cells were detected by Cell Counting Kit-8 (CCK-8), Wound scratch assay and transwell. Western blots were employed to detect the expression of Matrix metalloproteinase-2 (MMP-2) and epithelial-mesenchymal transition (EMT)-related factors in HEC-1A cells treated with rhOPN. Results: rhOPN promotes cell proliferation, migration and invasion in HEC-1A cells. rhOPN influenced EMT-related factors and MMP-2 expression in HEC-1A cells. rhOPN promoted HEC-1A cells migration, invasion and EMT through protein kinase B (PKB/AKT) and Extracellular regulated protein kinases (ERK1/2) signaling pathway. Conclusions: These results may open up a novel therapeutic strategy for endometrial cancer: namely, rhOPN have important roles in controlling growth of endometrial of cancer cells and suggest a novel target pathway for treatment of this cancer.
\end{abstract}

Y. Lia and Y. Xie contributed equally to this study and share first authorship.

Ying Kong and Hui Kong

KARGER 125
Department of Biochemistry and Molecular Biology, Dalian Medical University, 116044 Dalian, Liaoning, (China); and Department of Otorhinolaryngology of the Second Hospital, Dalian Medical University, Dalian 116023, Liaoning Province, (China) E-Mail yingkong@dlmedu.edu.cn and konghui_1969@163.com 


\section{Cellular Physiology Cell Physiol Biochem 2015;37:1503-1512

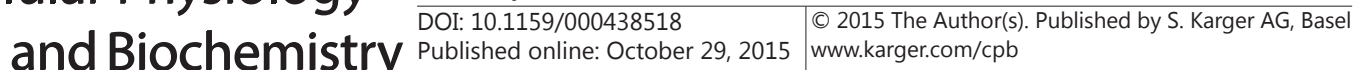 \\ Li et al.: Osteopontin Promotes HEC-1A Invasion and Migration}

\section{Introduction}

Endometrial carcinoma (EC) is the most common malignancy of the female genital tract and is increasing in frequency [1]. EC often causes abnormal postmenopausal bleeding as an initial symptom and is commonly detected as an early stage malignancy, with more than $75 \%$ of women with this disease diagnosed at stage I/II and the majority of them surgically curable $[2,3]$. Thus, the overall prognosis for EC is excellent, with a 5-year survival rate approximating $80 \%[4,5]$.

Tumor growth and metastasis requires a coordinated succession of events within the tumor microenvironment that involves proliferation, loss of cellular adhesion, degradation of the extracelluar matrix (ECM), invasion into host stroma, cell migration, and angiogenesis $[6,7]$. Growth factors and cytokines, serine proteases, matrix metalloproteinases (MMPs), cellular adhesion molecules, tumor cell stromal interactions, and phospholipids are actively involved in the regulation of these processes [8-10]. Thus, understanding the tumor microenvironment and its regulatory mechanism is critical for the development of effective therapies to treat metastatic endometrial carcinoma. Epithelial-to-mesenchymal transition (EMT) is important to tumor aggression and metastasis [11]. At a molecular level, EMT occurs as a result of the activity of some transcriptional factors, such as ZEB1/2, Twist and Snail, which suppress expression of the epithelial marker E-cadherin and induce the mesenchymal genes $\mathrm{N}$-cadherin and Vimentin [12]. However, the mechanisms and pathways that initiate EMT programs are not comprehensively understood

Osteopontin (OPN) is a SIBLING (small integrin-binding ligand, N-linked glycoprotein) that was first identified in 1986 in osteoblasts. OPN is an ECM molecule and is involved in many physiologic and pathologic processes, including cell adhesion [13], angiogenesis [14] and tumor metastasis $[15,16]$. OPN is a well-known multifunctional factor involved in various aspects of cancer progression, including endometrial cancer. OPN is postulated to bind to integrin receptors at the cell surface of human endometrium to mediate cellular adhesion and migration during embryo implantation [17]. There are conflicting reports about the expression of OPN in endometrial cancer $[18,19]$. Additionally, the molecular mechanisms that define the role of OPN in tumor progression and metastasis in endometrial cancer are incompletely understood.

In this paper, we were aimed to study the relationship between OPN and EC.

\section{Materials and Methods}

\section{Reagents}

Human uterine epithelial cell line HEC-1A cells were acquired from the American Type Culture Collection (ATCC). Recombinant OPN protein (rhOPN) was purchased from R\&D Systems. Rabbit antiAKT and phosphor-AKT (Ser473) antibodies were purchased from Bioworld Technology. Rabbit anti-ERK, phospho-ERK 1/2, glyceraldehyde 3-phosphate dehydrogenase (GAPDH) antibodies and U0126 (a specific inhibitor of MEK/ERK; 10-5M) and LY294002 (a specific inhibitor of p38; 10-6M) were purchased from Beyotime Institute of Biotechnology. MMP-2, E-cadherin, N-cadherin and Vimentin were purchased by Proteintech. Cell Counting Kit-8 was purchased by Dojindo. Enhanced chemiluminescence (ECL) assay kit was purchased from Amersham. Horseradish peroxidase (HRP)-conjugated anti-rabbit secondary antibody, anti-mouse secondary antibody, biotinylated secondary antibody, streptavidin-horseradish peroxidase and diaminobenzidine (DAB)-peroxidase substrate were purchased from ZSGB-BIO. TRITC-conjugated goat anti-rabbit secondary antibody IgG and FITC-conjugated goat anti-mouse secondary antibody were purchased from Thermo.

Cell lines and culture conditions

HEC-1A cells were grown in McCoy's 5A supplement with 10\% fetal bovine serum (FBS), $100 \mathrm{U} / \mathrm{mL}$ penicillin and $100 \mu \mathrm{g} / \mathrm{mL}$ streptomycin. Cells were maintained at $37^{\circ} \mathrm{C}$ under $5 \% \mathrm{CO}_{2}$ in humidified air. 


\section{Cellular Physiology Cell Physiol Biochem 2015;37:1503-1512 \begin{tabular}{ll|l} 
and Biochemistry Published online: October 29, 2015 & $\begin{array}{l}\text { (c) } 2015 \text { The Author(s). Published by S. Karger AG, Basel } \\
\text { www.karger.com/cpb }\end{array}$
\end{tabular}

\section{Cell Proliferation Assay}

Cell proliferation was detected by a Cell Counting Kit-8 assay. HEC-1A cells were suspended in McCoy's 5 A medium supplemented with $15 \%$ heat-inactivated fatal bovine serum and subsequently seeded in 96 well plates and incubated for $24 \mathrm{~h}$. After that, plates were divided into four groups treated with different concentration of rhOPN ( $0 \mathrm{ng} / \mathrm{ml}, 100 \mathrm{ng} / \mathrm{ml}, 200 \mathrm{ng} / \mathrm{ml}, 300 \mathrm{ng} / \mathrm{ml}$ and $400 \mathrm{ng} / \mathrm{ml})$. Then, plates were continued incubating 1 Days, 2 Days, 3 Days and 4 Days. After being incubated, the cultures were added $10 \mu \mathrm{l}$ CCK-8 solution to each well and incubated at $37^{\circ} \mathrm{C}$ for another $2 \mathrm{~h}$. Optical density (OD) value of absorbance at $450 \mathrm{~nm}$ was measured by Thermo Scientific Fluoroskan Ascent FL. The results were plotted as means \pm SEM of three independent experiments having three determinations per sample for each experiment.

\section{Wound scratch assay}

Cells were seeded into six-well plates and then cultured to $90 \%$ confluence. The confluent cell monolayer was wounded using a sterile $10 \mu \mathrm{l}$ pipette tip. The suspended cells were washed using normal growth medium. The scratch wound was captured after $48 \mathrm{~h}$ using an OLYMPUS IX81 microscope in three fields of view at $100 \times$ magnification. The area of the open wound was quantified using Photoshop (Adobe).

\section{Matrigel cell invasion assay}

For matrigel cell invasion assay, transwell inserts $(6.5 \mathrm{~mm}$, Costar) containing polycarbonate filters with $8 \mathrm{~mm}$ pores were precoated with $50 \mu \mathrm{l}$ of $1 \mathrm{mg} / \mathrm{ml}$ matrigel matrix (Becton Dickinson) at $37^{\circ} \mathrm{C}$ for $4 \mathrm{~h}$ for gelling. $1.0 \times 10^{5}$ of HEC-1A cells in serum-free medium were plated in the upper chamber, whereas medium with $10 \%$ FBS was added to the lower chamber. After incubating for $24 \mathrm{~h}$, the cells on the matrigel side of the inserts were removed by cotton swab. The inserts were fixed in methanol and stained with crystal violet. The number of invaded or migrated cells attached to the other side of the insert was counted under a light microscope (Olympus) in five random fields. Three independent experiments were performed. Numbers of invasive or migrated cells under different treatments were normalized to the control and expressed as a means of invasion or migration percentage $(\%) \pm$ SEM.

\section{Western Blot}

Cells were washed in PBS before incubation with Lysis Buffer (1\% Triton X-100, $150 \mathrm{mM} \mathrm{NaCl}, 10 \mathrm{mM}$ Tris, pH 7.4, 1 mM EDTA, 1 mM EGTA, pH 8.0, $0.2 \mathrm{mM} \mathrm{Na}_{3} \mathrm{VO}_{4}, 0.2 \mathrm{mM}$ phenylmethylsulfonyl fluoride, $0.5 \%$ Nonidet P-40) on ice for $10 \mathrm{~min}$. The cell lysates were clarified by centrifugation at 9,000 g for $15 \mathrm{~min}$ and the supernatants were collected. Protein concentration was determined with the Coomassie Protein Assay reagent using bovine serum albumin (BSA) as a standard. Equal amounts of protein extracts (30 $\mu \mathrm{g}$ ) were separated by $12 \%$ sodium dodecyl suphate (SDS)-polyacrtlamide gel electrophoresis (PAGE) and transferred to nitrocellulose filter (NC) membranes. The membranes were blocked in 5\% non-fatmilk in Tris-buffered saline containing 0.1\% Tween 20 (TBST) for 2 hours at room temperature and probed with primary antibodies overnight at $4^{\circ} \mathrm{C}$ (MMP-2, 1:400; N-cadherin, E-cadherin and Vimentin, 1:1000; AKT, p-AKT, ERK1/2 and p-ERK1/2, 1:500; GAPDH, 1:5000). The membranes were washed with TBST three times. Then the membranes were incubated with horseradish peroxidase-conjugated antibody for 1 hour at room temperature. After washed with TBST four times, the membranes were detected using ECL and visualized using Bio-Rad Laboratories. Western blots shown are representative of at least three independent experiments. Densitometry of each band for the target protein was quantified by densitometry analysis with Labworks 4.6. The protein ban intensity was quantified by the mean \pm SEM of three experiments for each group as determined from densitometry relative to GAPDH or AKT or ERK1/2.

\section{Gelatin zymography assay}

Cell culture media were standardized according to the protein contents and subjected to $10 \%$ SDSPAGE containing $1 \mathrm{mg} / \mathrm{ml}$ gelatin. After electrophoresis, the gel was washed at room temperature for $1 \mathrm{~h}$ in $2.5 \%$ triton $\mathrm{X}-100(\mathrm{v}: \mathrm{v}), 50 \mathrm{mM}$ TrisHCl (pH7.5) to remove SDS, and then incubated at $37^{\circ} \mathrm{C}$ overnight in a buffer containing $150 \mathrm{mM} \mathrm{NaCl}, 5 \mathrm{mM} \mathrm{CaCl}_{2}$ and $50 \mathrm{mM}$ Tris- $\mathrm{HCl}$ (pH7.6). The gel was subsequently stained with $0.1 \%(\mathrm{w} / \mathrm{v}$ ) Coomassie Brilliant Blue R- 250, and destained in 10\% (v/v) methanol and 5\% $(\mathrm{v} / \mathrm{v})$ glacial acetic acid to reveal zones with gelatinase activity. The results were analyzed using Image Jversion 1.47 software (NIH). All zymography experiments were repeated in triplicate. 


\section{Cellular Physiology Cell Physiol Biochem 2015;37:1503-1512

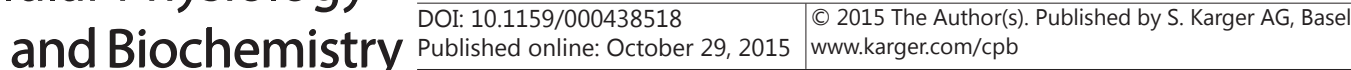 \\ Li et al.: Osteopontin Promotes HEC-1A Invasion and Migration}

Indirect Immunofluorescence staining

After washing with PBS, cells grown on coverslips were fixed in 4\% paraformaldehyde following 20 min and washed in PBS three times. Nonspecific binding sites were blocked by incubation with $1 \%$ goat serum in PBS at room temperature for $1 \mathrm{~h}$. Slides were incubated N-cadherin, E-cadherin and Vimentin antibody (all 1:100) overnight at $4^{\circ} \mathrm{C}$. After washing three times with PBS, slides were incubated with TRITCconjugated goat anti-rabbit antibody $(1: 100)$ for $1 \mathrm{~h}$ at $37^{\circ} \mathrm{C}$. After washed three times, slides were incubated with DAPI for $5 \mathrm{~min}$ at room temperature and washed three times again. Specimens were mounted in PBS containing $90 \%$ glycerol and $1.0 \%$ p-phenylenediamine and subsequently monitored under an Olympus BX51 immunofluorescence microscope.

Data analysis

All data were presented as the mean \pm standard error mean (SEM). Statistical analysis was performed using one-way ANOVA or t-test (for data normally distributed). ${ }^{*} P<0.05$, ${ }^{* *} P<0.01$.

\section{Results}

rhOPN promotes cell proliferation, migration and invasion in HEC-1A cells

We used different concentration of rhOPN $(0 \mathrm{ng} / \mathrm{ml}, 100 \mathrm{ng} / \mathrm{ml}, 200 \mathrm{ng} / \mathrm{ml}, 300 \mathrm{ng} / \mathrm{ml}$ and $400 \mathrm{ng} / \mathrm{ml}$ ) treated with HEC-1A cells firstly. The CCK-8 results showed that rhOPN could significantly increase the proliferation ability of HEC-1A cells. The proliferation ability of HEC-1A reached the peak at the point of $300 \mathrm{ng} / \mathrm{ml}$ (Fig. 1A). Then we used wound scratch assay and transwell to detect the migration and invasion ability of HEC-1A. We found that rhOPN could promote HEC-1A migration (Fig. 1B and D) and invasion (Fig. 1C and E). And the peak was both at the point of $300 \mathrm{ng} / \mathrm{ml}$.

rhOPN induced MMP-2 expression in HEC-1A cells

To determine whether OPN induces MMP-2 expression, HEC-1A cells were treated without or with rhOPN (300 ng/ml) for 4, 8, 12, 24, $48 \mathrm{~h}$ and the expression of MMP-2 was detected by western blot. The results indicated that rhOPN induced MMP-2 expression in a time-dependent manner in HEC-1A cells, and the protein expression of MMP-2 reached the peak at the point of $24 \mathrm{~h}$ (Fig. $3 \mathrm{~A}$ and B). We also studied the dose-dependent response of rhOPN $(24 \mathrm{~h})$ for $0,100,200,300$ and $400 \mathrm{ng} / \mathrm{ml}$. It showed that the protein expression of MMP-2 increased in a dose-dependent manner and that $300 \mathrm{ng} / \mathrm{ml}$. rhOPN induced the highest level of MMP-2 expression compared with other doses (Fig. 3C and D). We also used the Gelatin zymography assay to detect the expression of MMP-2, a key factor of cell migration and invasion. These results showed that the secretion of MMP-2 was obviously increased after treated with $300 \mathrm{ng} / \mathrm{ml}$ rhOPN than untreated group (Fig. 2E and F).

rhOPN influenced EMT-related factors expression in HEC-1A cells

We treated HEC-1A cells with rhOPN for $24 \mathrm{~h}$ at the concentration of $300 \mathrm{ng} / \mathrm{ml}$, then used western blot and Indirect Immunofluorescence staining to detect the expression of $\mathrm{N}$-cadherin, E-cadherin and Vimentin. The western blot results showed that the expression of $\mathrm{N}$-cadherin and Vimentin were significantly increased than untreated cells, and the expression of E-cadherin was decreased after treated with rhOPN (Fig. 3A, B, C and D). The immunofluorescence showed the same results (Fig. 3E).

rhOPN promoted HEC-1A cells migration, invasion and EMT through AKT and ERK1/2 signal pathway

To determine whether rhOPN promoted HEC-1A cells migration, invasion and EMT through p-AKT and pERK1/2 signal pathway, HEC-1A cells were treated with rhOPN at 0 $\mathrm{ng} / \mathrm{ml}, 100 \mathrm{ng} / \mathrm{ml}, 200 \mathrm{ng} / \mathrm{ml}, 300 \mathrm{ng} / \mathrm{ml}$ and $400 \mathrm{ng} / \mathrm{ml}$ for $24 \mathrm{~h}$ firstly. The expression of p-AKT and p-ERK1/2 were detected by western blot. Results indicated that rhOPN could 
Fig. 1. $r h O P N$ p r o m o t e $s$ HEC-1A cells proliferation, migration and invasion. (A) Cells were seeded in 96-well plates and detected the ability of HEC-1A cells proliferation by CCK-8; (B and D) Cells were seeded in 6-well plates and detected the ability of HEC-1A cells migration by Wound scratch assay (magnification, $\times 40$ ); (C and E) Cells were suspended in McCoy's 5A medium supplemented with 15\% heat-inactivated fatal bovine serum and subsequently seeded in 96-well plates and detected the ability of HEC-1A cells invasion by transwell (magnification, $\times 10)$.

A

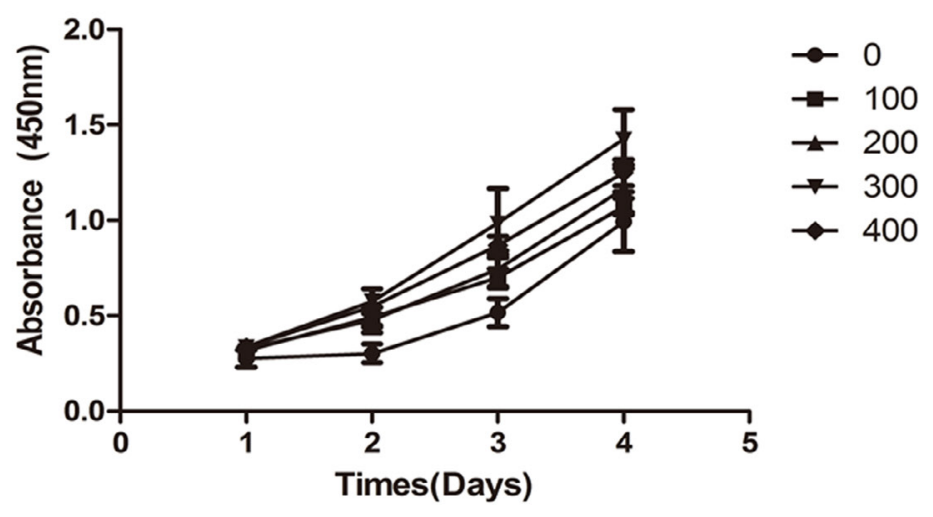

B

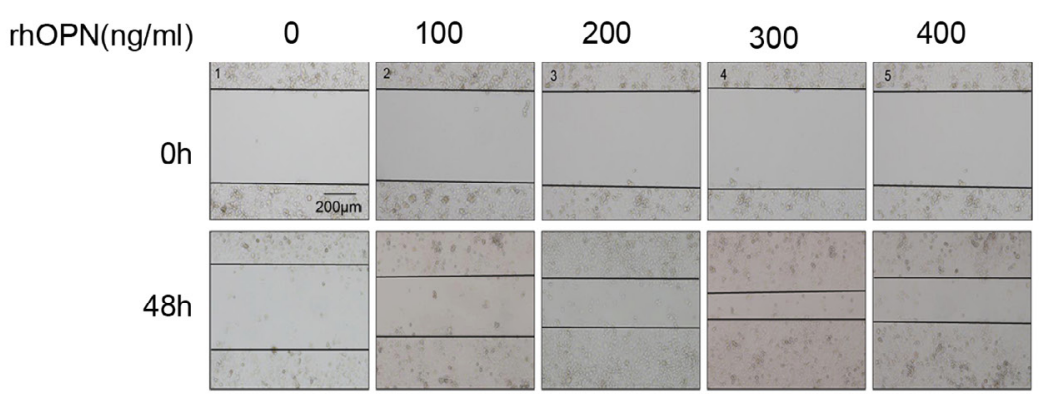

C

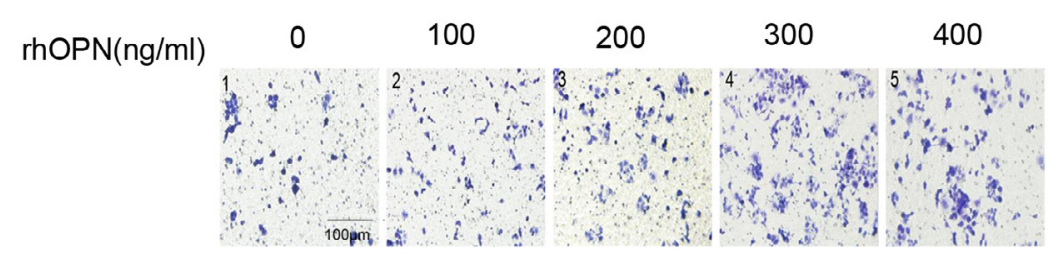

$D$

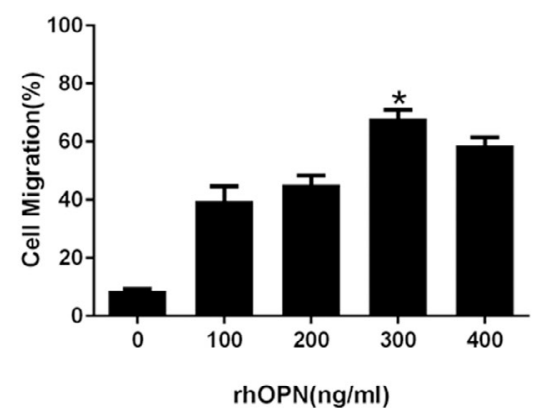

E

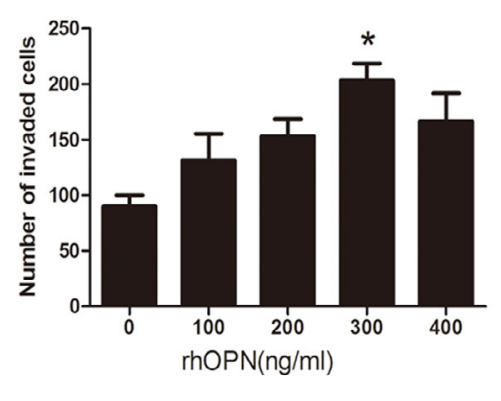

regulate AKT and ERK signal pathway (Fig. 4). Then we co-treated HEC-1A cells with rhOPN and LY294002/U0126. The results (Fig. 5 and 6) showed that LY294002 and U0126 can significantly decrease the expression of MMP-2, Vimentin and N-cadherin, while increased the expression of E-cadherin. Compared to treated with rhOPN group, co-treated with rhOPN and LY294002/U0126 group was obviously decreased the expression of MMP-2, Vimentin and $\mathrm{N}$-cadherin, while increased the expression of E-cadherin. 


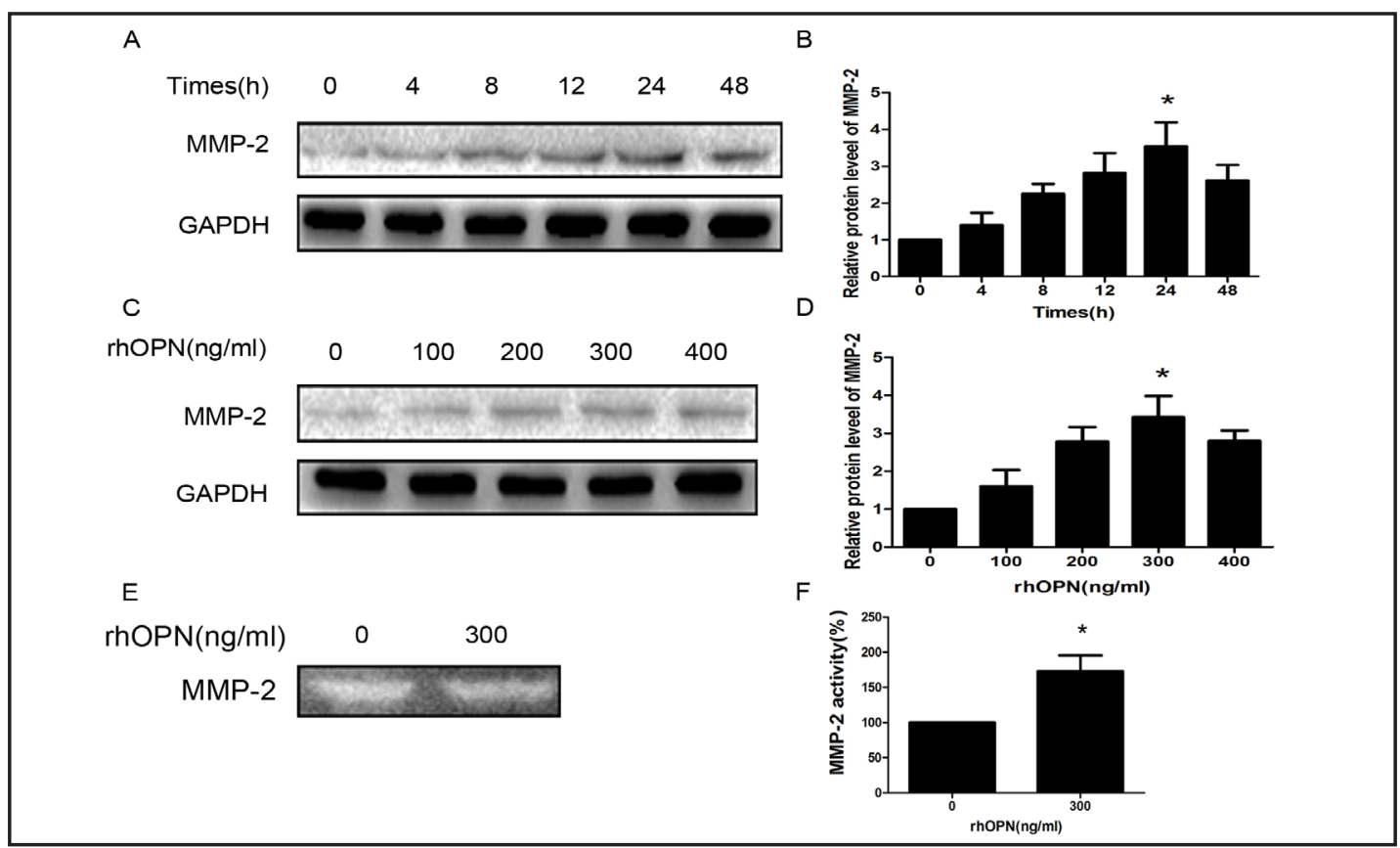

Fig. 2. Recombinant human OPN (rhOPN) induces MMP-2 expression and secretion (A and B). HEC-1A cells were treated with various concentrations of rhOPN for $24 \mathrm{~h}$; (C and D) HEC-1A cells were treated for various periods with rhOPN at a concentration of $300 \mathrm{ng} / \mathrm{ml}$. (E and F) HEC-1A cells were treated with rhOPN at $300 \mathrm{ng} / \mathrm{ml}$. ${ }^{*} P<0.05$.

Fig. 3. rhOPN influences E-cadherin, Vimentin and $\mathrm{N}$-cadherin expression in HEC-1A cells. (A-D) HEC-1A cells were treated with rhOPN at $300 \mathrm{ng} / \mathrm{ml}$ for $24 \mathrm{~h}$. Use western blot to detect the expression of E-cadherin, Vimentin and N-cadherin; (E) HEC-1A cells were treated with rhOPN at $300 \mathrm{ng} / \mathrm{ml}$ for $24 \mathrm{~h}$. Use immunofluorescence staining to detect the expression and location of E-cadherin, Vimentin and $\mathrm{N}$-cadherin (bar = $50 \mu \mathrm{m}$ ).

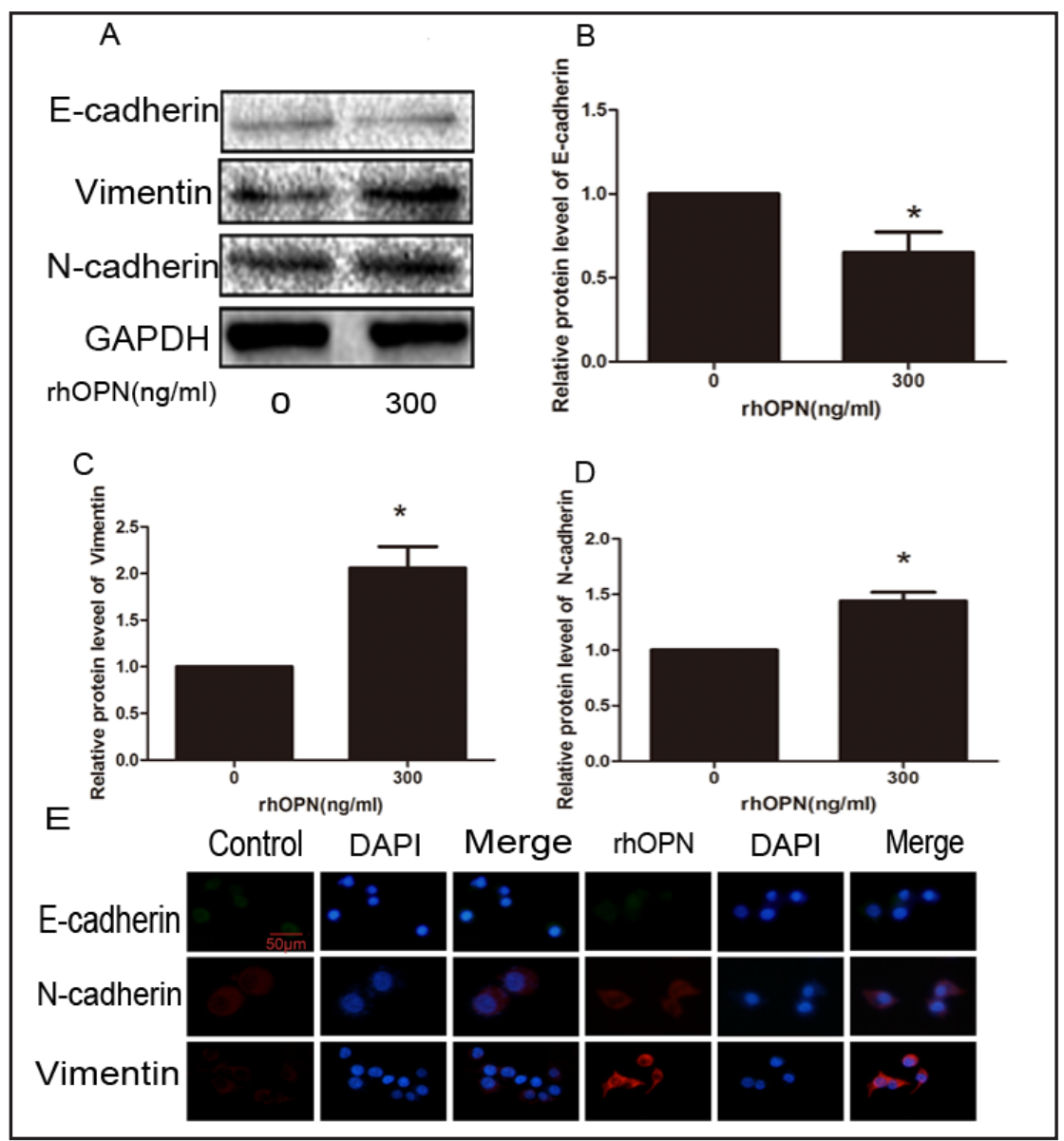




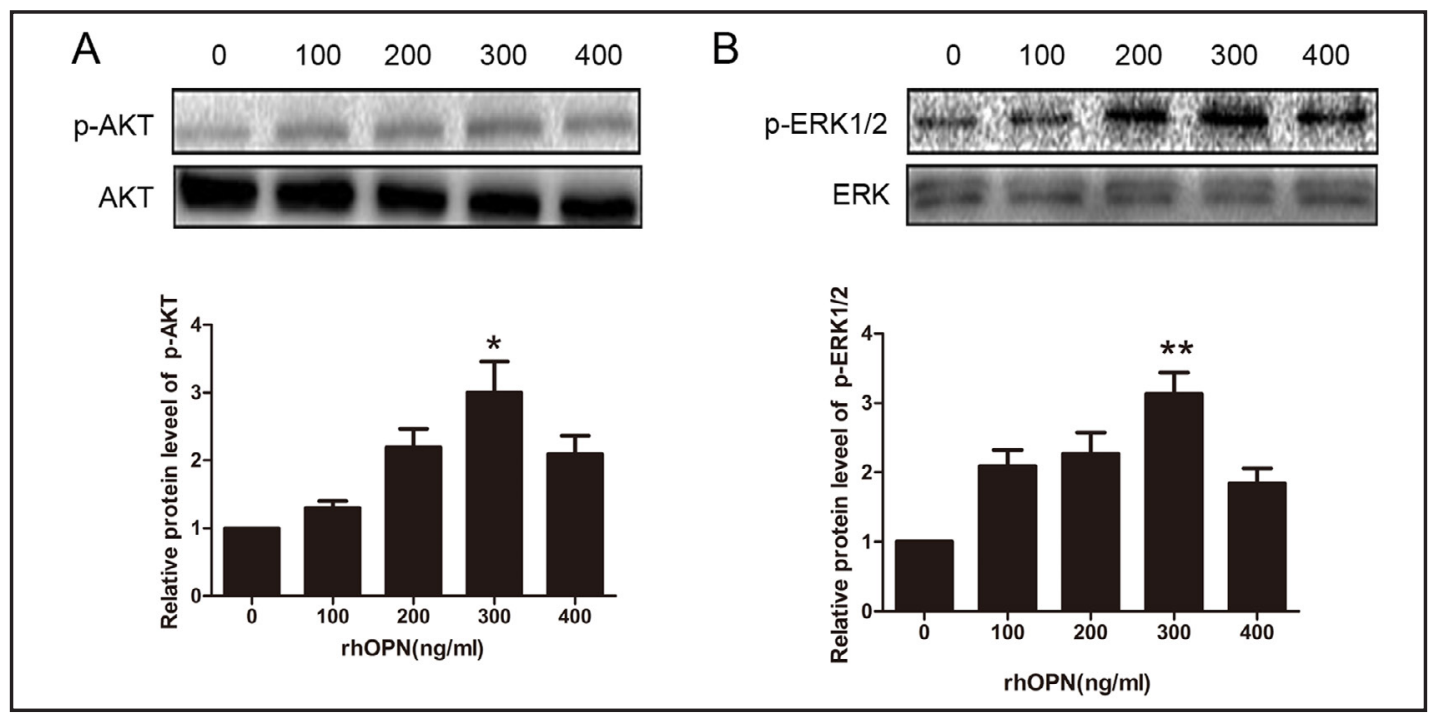

Fig. 4. Recombinant human OPN (rhOPN) stimulates ERK1/2 and AKT signaling pathway expression and secretion. HEC-1A cells were treated with various concentrations of rhOPN for $24 \mathrm{~h}$ (A) The expression of p-AKT and AKT were detected by western blot; (B) The expression of p-ERK1/2 and ERK1/2 were detected by western blot. $* P<0.05, * * P<0.01$.

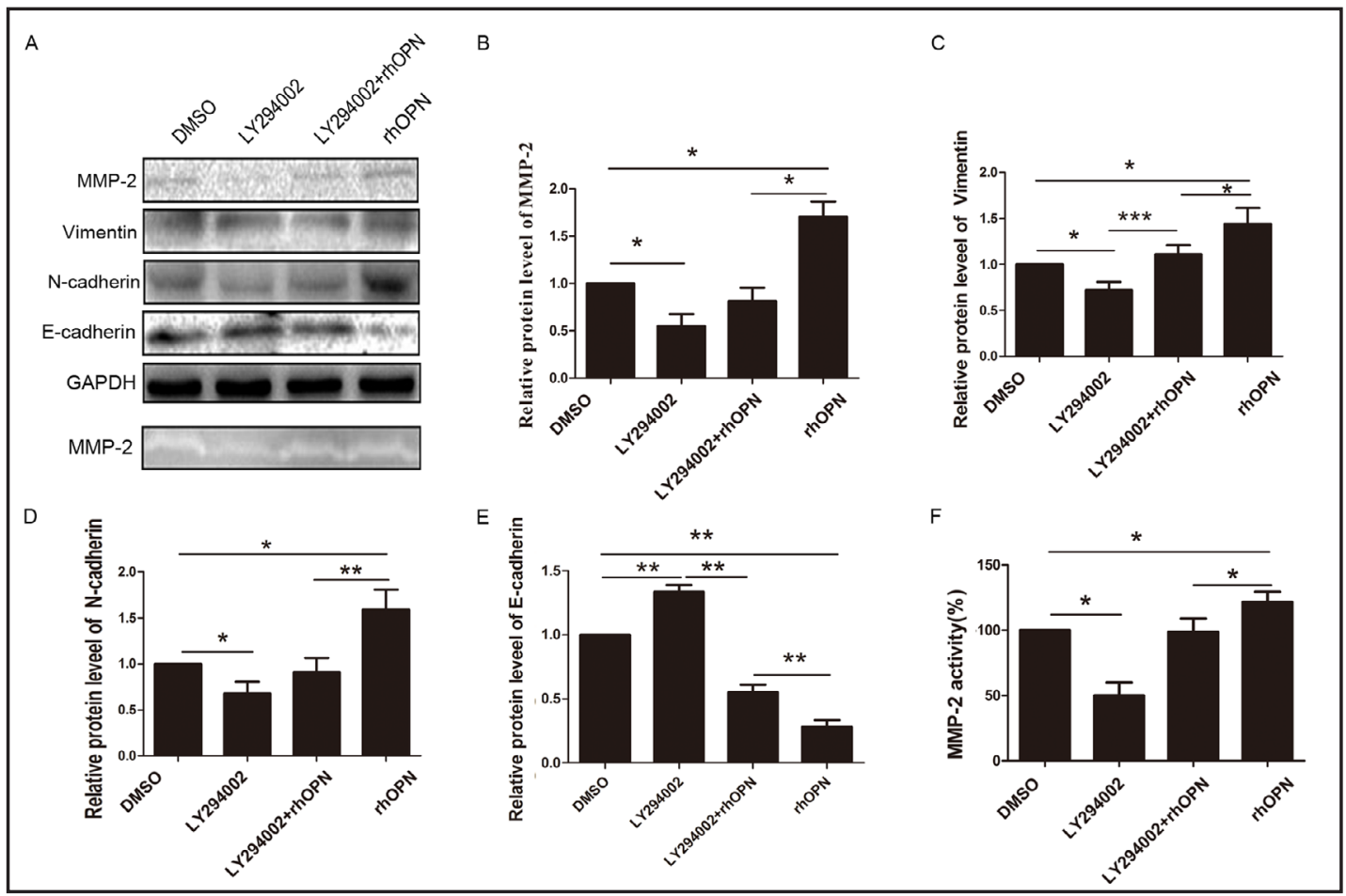

Fig. 5. rhOPN promotes EMT-related expression and MMP-2 secretion through AKT signaling pathway in HEC-1A cells. Cells were treated with LY294002 (a specific inhibitor of PI3K/AKT signaling pathway, 10-6 M) and/or rhOPN. The expression of MMP-2 (on the top of Fig. 5A), E-cadherin, Vimentin and N-cadherin were detected by western blot. The secretion of MMP-2 (at the bottom of Fig. 5A) was detected by Gelatin zymography assay. ${ }^{*} P<0.05,{ }^{* *} P<0.01,{ }^{* * *} P<0.001$.

\section{Discussion}

Endometrial carcinoma is one of the most common malignant diseases of female reproductive tract affecting 2-3\% of women. A major problem in the therapeutic KARGER 


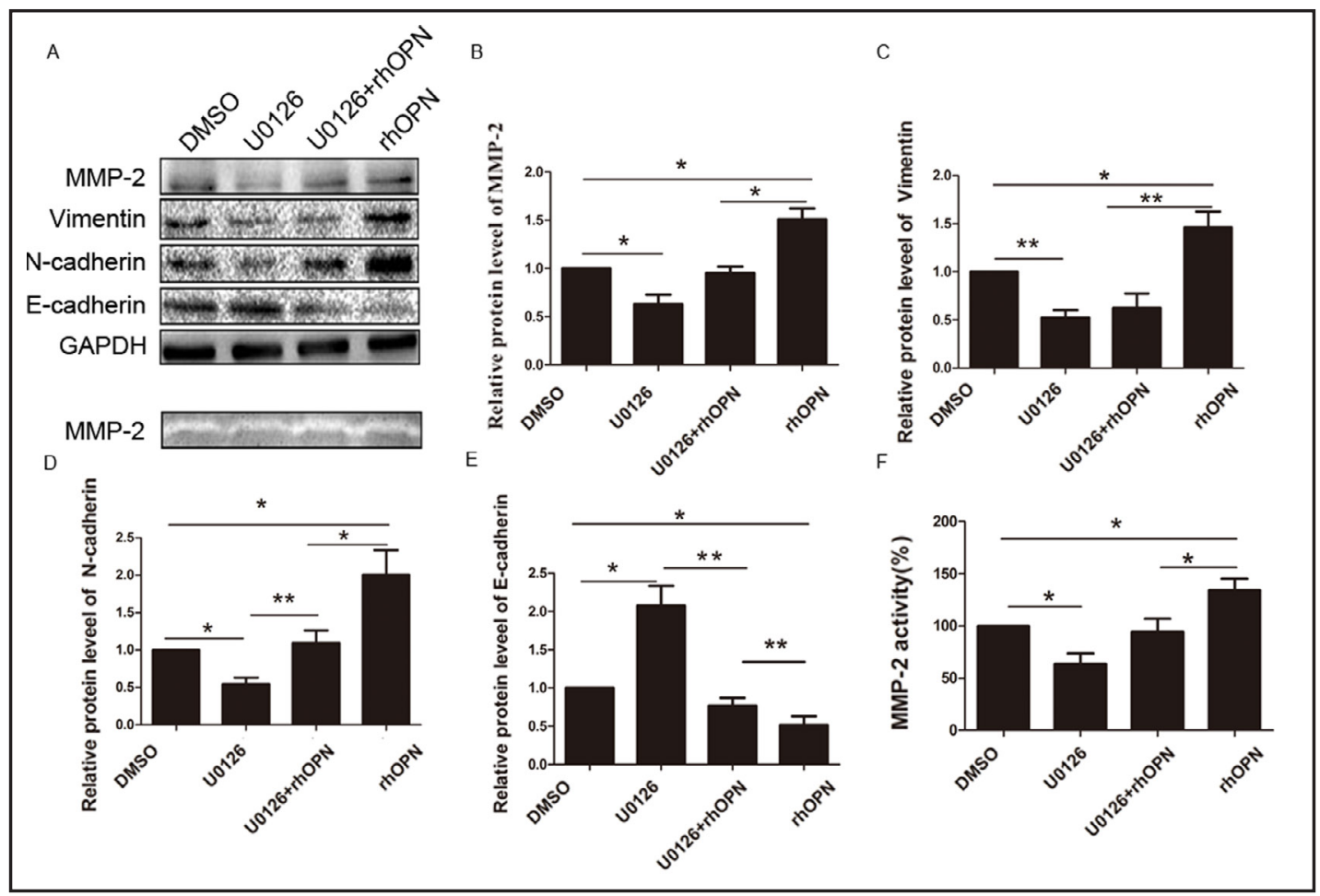

Fig. 6. rhOPN promotes EMT-related expression and MMP-2 secretion through ERK1/2 signaling pathway in HEC-1A cells. Cells were treated with U0126 (a specific inhibitor of ERK1/2 signaling pathway, $10^{-5} \mathrm{M}$ ) and/or rhOPN. The expression of MMP-2 (on the top of Fig. 6A), E-cadherin, Vimentin and N-cadherin were detected by western blot. The secretion of MMP-2 (at the bottom of Fig. 6A) was detected by Gelatin zymography assay. $* P<0.05,{ }^{* *} P<0.01$.

management of endometrial cancer is the growth and metastases in distant organs, but the genes orchestrating the process are yet to be identified for the rational design of new treatment.

OPN is a member of the extracellular matrix protein. It is a non-collagenous, sialic acid-rich, and glycosylated phosphoprotein $[20,21]$. It has an N-terminal signal sequence, a highly acidic region consisting of nine consecutive aspartic acid residues, and a GRGDS cell adhesion sequence predicted to be flanked by the $\beta$-sheet structure [22]. This protein has a functional thrombin cleavage site and is a substrate for tissue transglutaminase [21]. OPN binds with type I collagen [23], fibronectin [24], and osteocalcin [25]. Several highly metastatic transformed cells synthesize higher level of OPN than the nontumorigenic cells [26]. OPN causes cell adhesion, cell migration, ECM invasion, and cell proliferation by interacting with its receptor $\alpha \mathrm{v} \beta 3$ integrin in various cell types [27]. OPN induces proMMP- 2 activation by binding to its receptor $\alpha v \beta 3$ integrin $[28,29]$.

MMPs are ECM degrading enzymes that play critical role in embryogenesis, tissue remodeling, inflammation, and angiogenesis [30]. MMP-2 (also called type IV collagenase or gelatinase A) degrades several ECM proteins such as fibronectin, laminin, type I collagen, and proteoglycans [31]. Earlier reports have indicated that the increased levels of MMP-2 correlate with the invasive properties of several tumor cells [31, 32].

The EMT is a complex process involved in embryonic development, and was first recognized as a hallmark of embryogenesis in the early 1980s [33]. EMT is involved in tumor migration, invasion process and considered to play an important role in increasing cell invasion and metastatic potential of cancer cells [34]. During this process, epithelial cells lose their defining characteristics and acquire mesenchymal properties, including loss of cell-cell adhesion, increased motility and invasiveness, resistance to apoptosis and changes in cellular morphology [35]. The EMT has been identified as a driver of metastasis 
and tumor invasion, allowing cells to detach from their niche and migrate through blood and lymphatic vessels to invade different organs. That is to say that EMT makes tumor cells more invasion properties [36, 37].

In this paper, we found that rhOPN could promote HEC-1A cell migration, invasion and proliferation (Fig. 1) and increase MMP-2 expression and secretion (Fig. 2). It has been study that OPN can activate PI3K/AKT and ERK1/2 signaling. So we detected that rhOPN influenced these progressions through AKT and ERK1/2 signaling pathway (Fig. 4, 5, 6) [38, 39].

Since OPN can mediate cell adhesion, cell-cell interaction, invasion and colony formation in tumor cells in experimental systems, this molecule is a key candidate for a tumor prognostic marker and a potential target for therapeutic intervention in control of metastasis.

\section{Acknowledgments}

This work was supported by National Natural Scientific Grants (N0.30970646, 31570798), China, by Liaoning province natural science foundation of China (2014023055) and by the program for professor of special appointment in Liaoning province.

\section{Disclosure Statement}

None of the authors listed in this manuscript have a conflict of interest.

\section{References}

1 Jemal A, Siegel R, Ward E, Hao Y, Xu J, Murray T, Thun MJ: Cancer statistics, 2008. CA Cancer J Clin 2008;58:71-96.

2 Homesley HD, Boronow RC, Lewis JJ: Treatment of adenocarcinoma of the endometrium at memorialjames ewing hospitals, 1949-1965. Obstet Gynecol 1976;47:100-105.

3 Lotocki RJ, Copeland LJ, DePetrillo AD, Muirhead W: Stage i endometrial adenocarcinoma: treatment results in 835 patients. Am J Obstet Gynecol 1983;146:141-145.

4 Abeler VM, Kjorstad KE, Nesland JM: Undifferentiated carcinoma of the endometrium. A histopathologic and clinical study of 31 cases. Cancer-Am Cancer Soc 1991;68:98-105.

5 Morrow CP, Bundy BN, Kurman RJ, Creasman WT, Heller P, Homesley HD, Graham JE: Relationship between surgical-pathological risk factors and outcome in clinical stage i and ii carcinoma of the endometrium: a gynecologic oncology group study. Gynecol Oncol 1991;40:55-65.

6 Chambers AF, Groom AC, MacDonald IC: Dissemination and growth of cancer cells in metastatic sites. Nat Rev Cancer 2002;2:563-572.

7 Crissman JD: Tumor-host interactions as prognostic factors in the histologic assessment of carcinomas. Pathol Annu 1986;21:29-52.

8 Kopfstein L, Christofori G: Metastasis: cell-autonomous mechanisms versus contributions by the tumor microenvironment. Cell Mol Life Sci 2006;63:449-468.

9 Ruggieri S, Mugnai G, Mannini A, Calorini L, Fallani A, Barletta E, Mannori G, Cecconi O: Lipid characteristics in metastatic cells. Clin Exp Metastasis 1999;17:271-276.

10 Ariztia EV, Lee CJ, Gogoi R, Fishman DA: The tumor microenvironment: key to early detection. Crit Rev Clin Lab Sci 2006;43:393-425.

11 Salvesen HB, Haldorsen IS, Trovik J: Markers for individualised therapy in endometrial carcinoma. Lancet Oncol 2012;13:e353-e361.

12 Wik E, Raeder MB, Krakstad C, Trovik J, Birkeland E, Hoivik EA, Mjos S, Werner HM, Mannelqvist M, Stefansson IM, Oyan AM, Kalland KH, Akslen LA, Salvesen HB: Lack of estrogen receptor-alpha is associated with epithelial-mesenchymal transition and pi3k alterations in endometrial carcinoma. Clin Cancer Res 2013;19:1094-1105.

13 Johnson GA, Burghardt RC, Spencer TE, Newton GR, Ott TL, Bazer FW: Ovine osteopontin: ii. Osteopontin and alpha(v)beta(3) integrin expression in the uterus and conceptus during the periimplantation period. Biol Reprod 1999;61:892-899. 


\section{Cellular Physiology Cell Physiol Biochem 2015;37:1503-1512

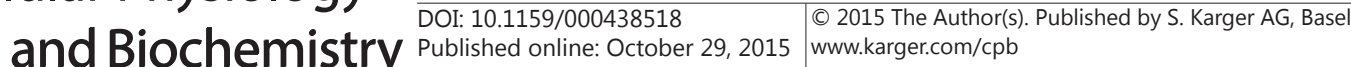

Li et al.: Osteopontin Promotes HEC-1A Invasion and Migration

14 Gupta A, Zhou CQ, Chellaiah MA: Osteopontin and mmp9: associations with vegf expression/secretion and angiogenesis in pc3 prostate cancer cells. Cancers (Basel) 2013;5:617-638.

15 Wai PY, Kuo PC: The role of osteopontin in tumor metastasis. J Surg Res 2004;121:228-241.

16 Zhang H, Guo M, Chen JH, Wang Z, Du XF, Liu PX, Li WH: Osteopontin knockdown inhibits alphav,beta3 integrin-induced cell migration and invasion and promotes apoptosis of breast cancer cells by inducing autophagy and inactivating the pi3k/akt/mtor pathway. Cell Physiol Biochem 2014;33:991-1002.

17 Apparao KB, Murray MJ, Fritz MA, Meyer WR, Chambers AF, Truong PR, Lessey BA: Osteopontin and its receptor alphavbeta(3) integrin are coexpressed in the human endometrium during the menstrual cycle but regulated differentially. J Clin Endocrinol Metab 2001;86:4991-5000.

18 Hashiguchi Y, Tsuda H, Bandera CA, Nishimura S, Inoue T, Kawamura N, Berkowitz RS, Mok SC: Comparison of osteopontin expression in endometrioid endometrial cancer and ovarian endometrioid cancer. Med Oncol 2006;23:205-212.

19 Briese J, Schulte HM, Bamberger CM, Loning T, Bamberger AM: Expression pattern of osteopontin in endometrial carcinoma: correlation with expression of the adhesion molecule ceacam1. Int J Gynecol Pathol 2006;25:161-169.

20 Butler WT: The nature and significance of osteopontin. Connect Tissue Res 1989;23:123-136.

21 Denhardt DT, Guo X: Osteopontin: a protein with diverse functions. Faseb J 1993;7:1475-1482.

22 Prince CW: Secondary structure predictions for rat osteopontin. Connect Tissue Res 1989;21:15-20.

23 Chen Y, Bal BS, Gorski JP: Calcium and collagen binding properties of osteopontin, bone sialoprotein, and bone acidic glycoprotein-75 from bone. J Biol Chem 1992;267:24871-24878.

24 Singh K, DeVouge MW, Mukherjee BB: Physiological properties and differential glycosylation of phosphorylated and nonphosphorylated forms of osteopontin secreted by normal rat kidney cells. J Biol Chem 1990;265:18696-18701.

25 Ritter NM, Farach-Carson MC, Butler WT: Evidence for the formation of a complex between osteopontin and osteocalcin. J Bone Miner Res 1992;7:877-885.

26 Craig AM, Bowden GT, Chambers AF, Spearman MA, Greenberg AH, Wright JA, McLeod M, Denhardt DT: Secreted phosphoprotein mrna is induced during multi-stage carcinogenesis in mouse skin and correlates with the metastatic potential of murine fibroblasts. Int J Cancer 1990;46:133-137.

27 Panda D, Kundu GC, Lee BI, Peri A, Fohl D, Chackalaparampil I, Mukherjee BB, Li XD, Mukherjee DC, Seides S, Rosenberg J, Stark K, Mukherjee AB: Potential roles of osteopontin and alphavbeta3 integrin in the development of coronary artery restenosis after angioplasty. Proc Natl Acad Sci U S A 1997;94:9308-9313.

28 Philip S, Bulbule A, Kundu GC: Osteopontin stimulates tumor growth and activation of promatrix metalloproteinase- 2 through nuclear factor-kappa b-mediated induction of membrane type 1 matrix metalloproteinase in murine melanoma cells. J Biol Chem 2001;276:44926-44935.

29 Scatena M, Almeida M, Chaisson ML, Fausto N, Nicosia RF, Giachelli CM: Nf-kappab mediates alphavbeta3 integrin-induced endothelial cell survival. J Cell Biol 1998;141:1083-1093.

30 Shapiro SD: Matrix metalloproteinase degradation of extracellular matrix: biological consequences. Curr Opin Cell Biol 1998;10:602-608.

31 Nagase H, Woessner JJ: Matrix metalloproteinases. J Biol Chem 1999;274:21491-21494.

32 Seftor RE, Seftor EA, Gehlsen KR, Stetler-Stevenson WG, Brown PD, Ruoslahti E, Hendrix MJ: Role of the alpha v beta 3 integrin in human melanoma cell invasion. Proc Natl Acad Sci U S A 1992;89:1557-1561.

33 Lim J, Thiery JP: Epithelial-mesenchymal transitions: insights from development. Development 2012;139:3471-3486.

34 Katsuno Y, Lamouille S, Derynck R: Tgf-beta signaling and epithelial-mesenchymal transition in cancer progression. Curr Opin Oncol 2013;25:76-84.

35 Heldin $\mathrm{CH}$, Vanlandewijck M, Moustakas A: Regulation of emt by tgfbeta in cancer. Febs Lett 2012;586:1959-1970.

36 Franco-Chuaire ML, Magda CS, Chuaire-Noack L: Epithelial-mesenchymal transition (emt): principles and clinical impact in cancer therapy. Invest Clin 2013;54:186-205.

37 Sanchez-Tillo E, Liu Y, de Barrios O, Siles L, Fanlo L, Cuatrecasas M, Darling DS, Dean DC, Castells A, Postigo A: Emt-activating transcription factors in cancer: beyond emt and tumor invasiveness. Cell Mol Life Sci 2012;69:3429-3456.

38 Zhang H, Guo M, Chen JH, Wang Z, Du XF, Liu PX, Li WH: Osteopontin knockdown inhibits alpha,beta integrin-induced cell migration and invasion and promotes apoptosis of breast cancer cells by inducing autophagy and inactivating the pi3k/akt/mtor pathway. Cell Physiol Biochem 2014;33:991-1002.

39 Kale S, Raja R, Thorat D, Soundararajan G, Patil TV, Kundu GC: Osteopontin signaling upregulates cyclooxygenase-2 expression in tumor-associated macrophages leading to enhanced angiogenesis and melanoma growth via alpha9beta1 integrin. Oncogene 2014;33:2295-2306. 